\title{
Чеботарева Ю.В. «Симфонизация» виртуозно-романтических концертов А. Вьётана
}

\begin{abstract}
Аннотация: В данной статье освещаются результаты исследования творчества одного из наиболее известных бельгийских музыкантов - Анри Въётана, чъе уникальное музыкальное дарование в полноте проявилось в композиторском творчестве и исполнительском искусстве. Несмотря на важное значение деятельности А. Въётана в развитии скрипичной музыки, его заслуги в области концертного жанра до сих пор не признаны в полной мере, в связи с чем объектом данного исследования послужили концерты для скрипки А. Въётана, а предметом изучения стали особенности скрипичного музыкального языка на основе синтезирования виртуозного и симфонического начал в концертном жанре. Статья направлена на выявление новаторских черт $A$. Въётана в жанре скрипичного концерта, которые рассматриваются с точки зрения стилистических особенностей, формообразования и принципов «симфонизации» музыкальной драматургии. Основой исследования является комплексно-теоретический подход, объединяющий историко-стилистический, сравнительный музыковедческий и жанровый методы анализа. В статье впервые дается оценка новаций А. Въётана в жанре скрипичного концерта с позиции выявления приемов симфонического развития. Обосновано, что применяемые композитором принципы музыкального развития свидетельствуют о его приверженности к лирико-драматическому (монологическому) типу симфонизма, что проявляется на уровне драматургии и на уровне выразительных средств. Автором сделаны выводы о том, что особенностью музыкального мышления А. Въётана является создание лирико-эпических образов романтического характера. В результате исследования раскрывается своеобразие трактовки А. Въётаном жанра скрипичного концерта, синтезирующего виртуозно-романтическую направленность с динамикой симфонического развития.
\end{abstract}

Ключевъе слова: Скрипичный концерт, Въётан, принципы симфонизации, симфоническое развитие, монологический тип симфонизма, романтизм, виртуозность, стилистическое синтезирование, музыкальный стиль, концертный циккл.

Review: The present article is devoted to the creative work of one of the most famous Belgium musicians Henri Vieuxtemps whose unique gift for music came in full force in his compositions and performing art. Despite the important role of Henri Vieuxtemps' activities in the development of violin music, his achievements in the sphere of concert genre are still not recognized the way they should be. In this regard, the author of the present article decides to make Henri Vieuxtemps' violin concerts as the object of the research. The subject of the resaerch is the peculiarities of the musical language of his violin which was based on the synthesis of virtuosity and symphony in the concert genre. The present article is aimed at defining inventive features of Henri Vieuxtemps in the genre of violin concert, which are being viewed from the point of view of style, form making and principles of 'symphonization' of musical dramatic composition. The research is based on the complex theoretical approach combining historical and stylistic, comparative musicological and genre methods of analysis. For the first time in the academic literature the author of the present article gives evaluation of Henri Vieuxtemps' innovations in the sphere of violin concert in terms of principles of symphonic development. It is proved that the principles of musical development used by the composer demonstrate his attribution to the lyrical dramatic (monological) type of symphonism, which become apparent at the level of his dramatic composition and expressive means. The author of the article concludes that the main peculiarity of Henri Vieuxtemps' musical thinking is his creation of lyrical epic images of the romantic nature. As a result of the research, the author describes Henri Vieuxtemps' unique interpretation of thegenre of violin concert through synthesizing virtuosity and romanticism with dynamics of symphonic development.

Keywords: Violin concert, Vieuxtemps, principles of symphonization, symphonic development, monological type of symphonism, romanticism, virtuosity, stylistic synthesizing, music style, concert cycle. 


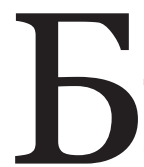
ельгийский скрипач, композитор и педагог - Анри Вьётан (1820-1881) - один из наиболее прогрессивных представителей музыкального романтического направления, оказавший значительное влияние на развитие скрипичного искусства. Деятельность Анри Вьётана получила большую известность среди его современников: личности и творчеству бельгийского скрипача и композитора посвящались многочисленные статьи и рецензии в европейских, а также русских газетах и журналах XIX века. Интерес к творчеству А. Вьётана не угас и в XX веке. Ведущие отечественные и зарубежные музыковеды (В. Григорьев, Л. Гинзбург, Л. Раабен, М. Куфферат, Ж. - Т. Раду) создавали монографические труды, посвященные жизни и творчеству этого выдающегося музыканта.

Композиторский дар бельгийского скрипача высоко оценивали многие критики, музыковеды, исполнители, композиторы, среди которых А.Н. Серов, А. Мозер, Р. Шуман, Э. Изаи, Г. Берлиоз, П.И. Чайковский. Сочетание музыкального содержания, ясной и изобретательной формы, поэтичности и благородства выразительной мелодики с виртуозной техникой, мастерски применяемой в соответствии с тонким пониманием природы выразительных средств - эти качества органично проявились в скрипичных концертах Анри Вьётана. Данный музыкальный жанр охарактеризовался новаторским высокохудожественным достижением композитора синтезированием черт виртуозно-романтического стиля с элементами симфонического развития, вслед за которым последовала и трансформация формы концертного жанра из трехчастного цикла к четырехчастному (Концерты №4 и №6) и контрастно-составному (Концерт №5). Трактовка скрипичной партии Вьётаном в концертном жанре органично соединила в себе стремление к яркой виртуозной приподнятости и героике романтизированного плана с тонкой лирико-поэтической выразительностью. При явном возвышении оркестровой партии над уровнем простого сопровождения, функция оркестра в скрипичных концертах выстраивалась таким образом, чтобы создать грамотный диалог с солистом, способствуя максимальному раскрытию выразительных средств солирующего инструмента.

Напомним, что со второй половины XVIII века, под влиянием активного развития симфонического жанра и стреми- тельного технического прогресса скрипичной игры, постепенно начала происходить эволюция инструментального концерта. В связи с явной симфонизацией и возрастающим интересом к виртуозно-художественным возможностям скрипки как яркого сольного инструмента, в концертном скрипичном жанре углубляется содержание, расширяется состав оркестра, а, следовательно, - обогащаются оркестровые краски, усиливается партия и роль солиста. Яркая индивидуальность, техническая свобода, экспрессия самовыражения стали основными характеристиками нового сформировавшегося типа скрипачей - солистов-виртуозов, выступавшие также в качестве композитора для своего инструмента. Однако большинство из этих произведений исчезали из репертуара, не представляя интереса вне авторской трактовки. Немногие сочинения виртуозов сохранили свое художественное значение. Среди тех, чей композиторский талант был равен исполнительскому мастерству, особое место принадлежит Анри Вьётану - создателю произведений, отражающих суть музыкальной эстетики эпохи.

Концерты Анри Вьётана преимущественно относятся к виртуозно-романтическому стилю. В то же время, сохраняя черты концертов виртуозного типа, в концертах Вьётана прослеживается явное тяготение к симфонизации жанра. Как «истинно симфонический концерт» был отмечен Л.С. Ауэром Первый скрипичный концерт А. Въётана (1839 г.), где, прежде всего, выделялась масштабность оркестровки $[1$, с. 183$]$. О качестве инструментовки этого концерта с большим одобрением отзывался Гектор Берлиоз: «Его Концерт E-dur - прекрасное произведение, великолепное в целом, оно заполнено интересными деталями как в сольной партии, так и в оркестре, инструментованном с большим мастерством. Ни один артист оркестра не забыт в партитуре; он заставил каждого сказать что-нибудь «пикантное». Он добился неимоверного эффекта в divisi скрипок, разделенных на 3-4 партии с альтом в басу, играющих тремоло во время аккомпанемента соло главной скрипке. Это свежий, необычный прием. Королева скрипка парит над маленьким дрожащим оркестром и заставляет вас сладко мечтать, как мечтают в ночной тиши на берегу озера» [7, с. 30, 50, 63].

Новаторские черты музыкального мышления композитора проявляются сразу же в 
симфонически развитых оркестровых tutti в первой части, в частности пространное оркестровое вступление, образующее первую экспозицию. В этом Вьётан продолжает и развивает традиции великого романтика-виртуоза Н. Паганини (1782-1840), создателя «большого» романтического концерта с расширенными оркестровыми tutti, чье искусство также оказало влияние на формирование музыкального языка в творчестве бельгийского музыканта. Среди концертов А. Въётана, где оркестровое вступление образует как бы первую экспозицию, подобный пример не единичен - первая часть Шестого концерта G-dur - Allegro moderato - написана в форме сонатного allegro c двойной экспозицией, но с неполной репризой. Преодоление формы классического сонатного allegro проявляется в отходе от его канонов при вступлении скрипичной партии. Сольная экспозиция сильно отличается от оркестровой и начинается с энергичной темы героического характера. Неоклассическая форма первой части E-dur'ного концерта достаточно едина по образному и тематическому содержанию, но во втором соло заметно появление нового тематического элемента связки, который в классических произведениях бывает достаточно коротким, здесь же, наоборот, получает широкое развитие. Романтические черты концерта проявляются в особом, импровизационном характере мелодики, насыщении формы большими виртуозными эпизодами, «блестящими» каденциями. Масштабность драматического образа и сложность музыкального языка Первого скрипичного концерта А. Вьётана получили высокую оценку Э. Изаи: «Этот концерт делает эпоху. С него начинается эра прогресса. И если бы даже Анри Вьетан не написал ничего другого, он был бы великим композитором» [2, с. 229].

Продолжение стремлений наполнения музыкальной формы приемами симфонизации, радикального усложнения фактуры, требующего незаурядного исполнительского мастерства, мы обнаруживаем в одном из самых романтичных и ярких произведений Анри Въётана - Четвертом скрипичном концерте. Новизна его творения была такова, что композитор долго не решался сыграть его публично и исполнил лишь в Париже в 1851 году (написан в 1849 году). Известный немецкий композитор и музыковед Арнольд Шеринг (1877-1941), при всем своем скептическом отношении к французской инструментальной музыке, признавал новаторское значение данного произ- ведения: «Вьетана-композитора скрипичного концерта можно было бы с известными оговорками и ограничениями поставить рядом с Листом. ...Его можно отнести к наиболее ценному в романской скрипичной литературе... B концерте d-moll перед нами произведение, связанное с реформой этого жанра. Не без колебания композитор решился издать его. Он боялся возбудить протест новой формой своего концерта. В то время когда концерты Листа были еще неизвестны, этот концерт Вьетана мог, пожалуй, вызвать нарекания» [8, с. 210]. Однако, подобному опасению г-на Шеринга не дано было реализоваться. П. И. Чайковский характеризовал Четвертый концерт А. Вьётана как «чудеснейший, эффектный, красивый, поэтически задуманный и отлично инструментованный» [4, с. 99]. Г. Берлиоз назвал концерт «великолепной симфонией с солирующей скрипкой» $[6$, с. 6o]. Четвертый скрипичный концерт вызывал особое восхищение критика А. Н. Серова: «Это не просто искусное сочинение мастерски преодоленных виртуозных трудностей, а музыка, хорошая музыка, со взмахами кисти чисто симфоническими, с превосходным оркестровыми сочетаниями, с теплотою и серьезностью внутреннего направления. Тут есть, одним словом, музыкальность истинная, которой зачастую и следов не оказывается в том, что играют и пишут гг. пресловутые виртуозы» [3, с. 79].

Романтические черты творчества А. Вьётана подтверждаются в особой приверженности композитора к лирико-драматическому (монологическому) типу симфонизма. В частности, в концерте d-moll автор применяет характерные для данного типа музыкальной драматургии приемы симфонизации. В частности, об используемом в концерте приеме создания тематических арок, пишет следующим образом Э. Изаи, отмечая тематическое единство различных разделов произведения: «...широкое симфоническое tutti; речитатив; каденция не в конце, а вначале первой части; Adagio; Scerzo; перед финалом медленное вступление, заимствованное из первых тем; tutti воспроизводит тему каденции; в середине финала фрагментарный мелодический эпизод в миноре и блестящее заключение. Таков концерт. Где же и у кого до Вьетана можно найти подобную форму? Она далека от Паганини, Виотти, Шарля Берио. Здесь перед нами, несомненно, творение столь же нетипичное, сколь удачное и замечательное» [2, с. 234]. 
Концерт № 4, d-moll, А. Вьётана - это четырехчастное произведение, своеобразное «симфоническое» полотно, насыщенное многими оркестровыми красками, демонстрирующее слушателю развернутый художественный образ. Вьётан сознательно расширяет традиционную для музыкального классицизма трехчастную форму концерта до четырехчастности, более характерной для симфонического жанра. При этом композитор радикально обновляет саму логику цикла: в качестве первой части концерта вместо Allegro здесь выступает Andante. Драматическую завязку действия композитор сознательно заменяет лирическо-эпическим началом. Отметим, что это весьма характерно для романтизма, в котором изменяются представления о смысле жанров. В романтическом искусстве жанр лишается классицистской обязательности смысло- и формообразующих признаков, его задачей становится отражение свободных от ограничений творческих импульсов человека. Музыкальное произведение теперь уподобляется некоему эвристическому исследованию, темой которого становится процесс самопознания и самораскрытия.

Романтическая сложность и рафинированность мелодики, фактуры, гармонии требует мастерства в овладении приемами виртуозной техники. Услышав на парижской сцене Пятый скрипичный концерт a-moll A. Въётана (1859 г.) в исполнении автора, Г. Берлиоз написал: «Если бы Вьетан не был таким великим виртуозом, его бы прославляли как композитора» [5, с. 299]. Э. Изаи говорил о вьётановском шедевре не только как о самом красивом, но и как о самом трудном из концертов Вьётана: «Трудный прежде всего из-за обилия изящных пассажей. ...требуемая виртуозность не может достигать цели, если исполнитель буде пользоваться ею не только с высочайшей легкостью, но и вкладывая в нее весьма ощутимую чувствительность. «Не играй пассажи, - повторял маэстро, - я никогда не писал их!» Подтекст этого замечания означал: не делай ничего того, что не служит целью и средством эмоции, поэзии, сердца» [2, с. 236].

B Пятом скрипичном концерте a-moll A. Въётан вновь демонстрирует тенденцию к радикальному изменению структуры цикла: несмотря на контрастирующие между собой разделы (Allegro non troppo, каденция, Adagio, Allegro con fuoco) данный концерт представляет собой одночастную форму, в которой можно выделить несколько контрастных эпизодов. В качестве драматургического принципа здесь используется характерный для жанра концерта принцип контрастного сопоставления ярких эпизодов, блестящих колористических средств и виртуозной фактуры с кантиленными темами. Такой «мозаичный» принцип построения Пятого концерта привносит особый динамизм и напряжение в процесс симфонического развития.

Разнообразие тем и образов внутри этого одночастного концерта сближает его по стилистике с жанром симфонической поэмы, появившимся в творчестве композиторов-романтиков. Творческая фантазия Вьётана неисчерпаема в изобретении удивительных по красоте тем, в которых выражается органическое сочетание выразительного и изобразительного начал. Три восходящих пассажа, открывающие скрипичное соло a-moll'ного концерта уподобляются образам восходящего солнца. Здесь мы отмечаем использование характерного для романтизма и символизма приема музыкальной драматургии - введение в музыкальную ткань тем-символов, приобретших позднее особое значение в оперной музыке Р. Вагнера.

Обобщая вышесказанное, отметим, что выявленные в результате исследования скрипичных концертов А. Вьётана принципы музыкальной драматургии доказывают присутствие в творчестве данного композитора черт романтического стиля. Композитор тяготеет к лирико-драматическому (монологическому) типу симфонизма. Он проявляется на уровне драматургии (создание тематических арок, применение монотематизма как способа изложения и развития музыкального материала) и на уровне выразительных средств (усиление выразительных возможностей сольного и оркестрового звучания за счет усложнения фактуры, гармонии, динамизации музыкального процесса при помощи введения контрастных эпизодов).

Романтический стиль в скрипичных концертах А. Вьётана проявляется в усилении авторского, индивидуального начала в процессе творчества, выражающемся в создании новых, нетрадиционных концертных форм (четырехчастной, одночастной), изменении логики концертного цикла. Своеобразие его творчества определяется тем художественным напряжением, которое образуется в процессе синтезирования черт виртуозно-романтического стиля с элементами симфонического развития. 
Искусство Анри Вьётана - один из важнейших периодов в становлении и развитии основных тенденций мирового скрипичного искусства. Примененные им в жанре скрипичного концерта принципы симфонизации музыкальной драматургии оказали несомненное влияние на музыкальное искусство последующего времени. Отдавая дань уважения рациональности ушедшего классицизма и эффектности современного композитору романтизма, предвосхищая эклектику и радикализм перемен искусства будущего, Анри Въётан создал свой индивидуальный стиль. Его творческое наследие объединяет художественные принципы классицизма и романтизма, отражает процесс усиления экспрессии и свободы творческого самовыражения.

\section{Библиография:}

1. Ауэр, Л. Моя школа игры на скрипке. Интерпретация произведений скрипичной классики. - М.: Музыка, 1965. $-274 \mathrm{c}$.

2. Изаи, Э. Анри Вьетан - мой учитель / Музыкальное исполнительство: Восьмой сборник статей / Сост. Г.Я. Эдельман. Ответств. ред. А.А. Николаев. Общая редакция Г.Я. Эдельмана и В.А. Натансона. - М.: Музыка, 1973. - 240 c.

3. Театральный и музыкальный вестник, 1860. - № 10.

4. Чайковский, П.И. Музыкально-критические статьи. Второе издание. - М.: Гос. муз. изд., 1953. -437 с.

5. Gregoir, Ed. Les artistes-musiciens belges an XVIII-me et an XIX-me siècles. - Bruxelles, 1888. - 294 p.

6. Journal des Debats. Paris: L. - Fr. Bertin, 1852 / Гинзбург Л. Анри Вьетан: Монография. - М.: Музыка, 1983. $-176 \mathrm{c}$.

7. Radoux, J. - Th. Vieuxtemps. Sa vie, ses oeuvres. - Liège, 1891(переизд. 1983г.). - 166 p.

8. Schering, A. Geschichte des Instrumentalkonzerts. - Leipzig: Breitkopf, 1927. - $235 \mathrm{~s}$

\section{References (transliterated):}

1. Auer, L. Moya shkola igry na skripke. Interpretatsiya proizvedenii skripichnoi klassiki. - M.: Muzyka, 1965. $274 \mathrm{~s}$.

2. Izai, E. Anri V'etan - moi uchitel' / Muzykal'noe ispolnitel'stvo: Vos'moi sbornik statei / Sost. G.Ya. Edel'man. Otvetstv. red. A.A. Nikolaev. Obshchaya redaktsiya G.Ya. Edel'mana i V.A. Natansona. - M.: Muzyka, 1973. $240 \mathrm{~s}$.

3. Chaikovskii, P.I. Muzykal'no-kriticheskie stat'i. Vtoroe izdanie. - M.: Gos. muz. izd., 1953. - 437 s.

4. Gregoir, Ed. Les artistes-musiciens belges an XVIII-me et an XIX-me siècles. - Bruxelles, 1888. $-294 \mathrm{r}$.

5. Journal des Debats. Paris: L. - Fr. Bertin, 1852 / Ginzburg L. Anri V'etan: Monografiya. - M.: Muzyka, 1983. $-176 \mathrm{~s}$.

6. Radoux, J. - Th. Vieuxtemps. Sa vie, ses oeuvres. - Liège, 1891(pereizd. 1983g.). - $166 \mathrm{r}$.

7. Schering, A. Geschichte des Instrumentalkonzerts. - Leipzig: Breitkopf, 1927. - $235 \mathrm{~s}$ 